\title{
Justice for All? Accountable Translations of Texts on Indigenous Law
}

\author{
Idette Noomé \\ Department of English, University of Pretoria, South Africa \\ idette.noome@up.ac.za
}

\begin{abstract}
This article addresses challenges arising from the guarantee in South Africa's Constitution (1996) of continued use of indigenous law. This law has been handed down in oral form, but increasingly, written sources are needed when cases relating to indigenous law are heard in South Africa's higher courts. Although access to this kind of information is vital to empowerment and justice in Africa, wider access is hampered by different literacy levels and language differences. This article examines accountable translation into English of legal anthropological texts, referring to a case study on law practised among the Nkuna of Ritavi to demonstrate some of the complexities. The article considers the Anglo-American translation tradition's preference for idiomatic translation (paraphrasis) rather than word-for-word faithfulness (metaphrasis). It advocates focusing on the Skopos (purpose) of texts negotiated with the author. It also proposes foregrounding the hermeneutic engagement of translators as readers. For the text in the case study, it suggests two translations, for two audiences: one into an academic register (for academics, legal experts, and educated members of the Nkuna community), and one into Plain English (mainly for members of the Nkuna community for whom English is a second language). To address political dimensions of responsible translation, metatextual strategies espoused by feminist translators to increase translators' visibility and accountability can be used, and postcolonial translation theory should be considered.
\end{abstract}

Keywords: hermeneutics; indigenous law; Nkuna; South Africa; translation theories; translator's visibility 


\section{Introduction}

South Africa's national legal system is a Common Law system, but much of South Africa's population is also served by indigenous law (also known as customary, traditional or tribal law). Indigenous law therefore continues to be practised, particularly by people who live in the country's rural areas and even some urban areas that fall under traditional authorities. Chapter 12 of the Constitution of the Republic of South Africa, Act 108 of 1996, guarantees that the 'institution, status and role of traditional leadership, according to customary law, are recognised, subject to the Constitution' (South Africa 1996). Moreover, the Law of Evidence Amendment Act, 47 of 1988 (South Africa 1988) provides that all courts are authorised to take judicial notice of indigenous law, which has jurisdiction over most matters of private law in other words, marriages, divorces, custody of children, property, inheritance and succession - the very essence of people's daily lives. Individual ethnic groups and subgroups have their own sets of principles, most of which have been passed down in oral form, and for which the written sources are limited. Where written sources do exist, they are mostly legal anthropological studies (many in Afrikaans) and isolated court records - providing limited access to those who need the information.

The system has the advantage that traditional leaders 'usually have intimate knowledge of the local customs and indigenous law system, the parties, and the circumstances under which they live' (Kleyn and Viljoen 2010:193). Moreover, these local courts speak the local language, eliminating the need for interpreters. The people who are involved in a case do not have to travel long distances, and thus save time and costs. There is also far less of a court backlog than in the mainstream Common Law system. The overall saving to the State and benefit to the community becomes clear when one considers the following comment on the application of indigenous law by the Nkuna, a Tsonga group:

Only a small percentage of the cases that arise within tribes actually end up in the magistrates' courts. In the case of the Nkuna of Ritavi, in 1984, only three of about 160 cases heard in the court of the hosi (tribal head) went to the magistrate's court on appeal, whereas an estimated 1 700 cases are heard annually in the courts of the 31 ward heads in the tribal area.] (Boonzaaier 1990:30-31; my translation)

However, the role of the indigenous courts in South Africa's justice system is not well defined (Kelto 2012). The Constitution guarantees the recognition of customary law, but also equality and human dignity. Indigenous law, which affects the quality of people's daily lives, sometimes potentially infringes on people's rights, especially women's constitutional rights. Hence, cases are increasingly tested in the country's 
higher courts, instead of being heard only at the family, ward and tribal levels where indigenous law is primarily practised. Since the landmark case of Bhe and Others $v$ Magistrate, Khayelitsha, and Others; Charlotte Shibi v Mantabeni Freddy Sithole and Others; SA Human Rights Commission and Others $v$ President of the Republic of South Africa and Others, 20051 SA 580 (CC) was heard in the Constitutional Court in 2005, setting a precedent for other cases to come before the higher courts at a national level, the application of indigenous law has become much more complex. Hence, the need for reliable academic resources (which many interpret to mean written sources) on the specifics of particular ethnic groups' laws has become more urgent, to supplement oral sources on such law. If texts such as academic legal anthropological studies are not available in a language accessible to those who need the information, these texts require translation, and such translations should preferably not be mere ad hoc translations of potentially relevant excerpts.

This article examines some challenges surrounding translations of such material, using a case study to demonstrate some of the problem areas. The sample text is an unpublished thesis, 'Die Familie-, Erf-, en Opvolgingsreg van die Nkuna van Ritavi met Verwysing na Ander Aspekte van die Privaatreg' ['The Family Law, Law of Inheritance and Law of Succession of the Nkuna of Ritavi with Reference to Other Aspects of Private Law'], by C.C. Boonzaaier (1990). The text is written in Afrikaans and records ethnographic research on the law of the Nkuna, a Tsonga group who live in the Tzaneen area in the north of South Africa. Extracts from this text have already been used as a source in the 2013 case of Modjadji Florah Mayelane $v$ Mphephu Maria Ngwenyama and Another. CCT 57/12. [2013] ZACC 14. A single Afrikaans copy of an earlier version of the text has also been used by a few members in the tribal court in Ritavi who do speak Afrikaans, since 1987, when Boonzaaier submitted a report containing much of the material recorded for his thesis. It was in fact a suggestion by a senior member of this court that provided the impetus for exploring and undertaking the translation referred to in the article, because so few members of the court have access to the text in Afrikaans. ${ }^{1}$

If a translation is to be accountable and useful, the translator, those who commission a translation, and the readers need to ask themselves who is translating what, for whom, why and how. They should also ask what might (deliberately or inadvertently) be added to or removed from a text in the process of decoding and recoding when the translator as a reader becomes a creative or recreative author. This article therefore explores some hermeneutic processes and explicit decisions involved in the reading/recoding of such texts by the translator as reader/author against the epistemological background of translation theory, and calls for two translations of this text - the first an accurate academic translation and the other a translation into Plain English, for the South African context. 


\section{Invisible Translators and Anglo-Centric Translations}

In the preface to Venuti's (1995) The Translator's Invisibility, post-colonial theorists Bassnett and Lefevere (1995:vii) state that

Translation is, of course, a rewriting of an original text. All rewritings, whatever their intention, reflect a certain ideology and a poetics and as such manipulate literature to function in a given society in a given way. Rewriting is manipulation, undertaken in the service of power... (emphasis added)

This statement implies, firstly, that a translator is a conscious author, situated in a specific historic moment, not merely a neutral transmitter of the words of another, and secondly, that the translator as author may have an agenda. It implies, thirdly, that the theory focuses on literature. What the statement omits is a focus on the fact that a translator has to be a reader before becoming an author. Like much translation theory, it also ignores the vast majority of translations - texts that contain information which people need to access to make sense of their world and to make decisions, such as the academic text considered in this case study.

Venuti (1995:1) and feminist translators such as Flotow (1997:3) point out the 'invisibility of the translator' in the Anglo-American tradition of translation, where the main focus is on 'transparent' translation, in other words, where the reader does not recognise that the text is translated at all, and the foreignness of the material is smoothed out. This assumption is not self-evident - it implies a sacrifice of faithfulness or accuracy for the sake of beauty (always an issue of debate in translation, epitomised by the rather sexist axiom attributed to Yevtushenko (n.d.:n.p.) that 'Translation is like a woman. If it is beautiful, it is not faithful. If it is faithful, it is most certainly not beautiful.') This tradition focuses on style, ignoring issues such as the translation's 'accuracy, its intended audience, its economic value ... its place in the translator's career' (Venuti 1995:2). The problem is compounded by an individualistic conception of authorship (Venuti 1995:6) and the ambiguous legal status of translation (Venuti 1995:8), as reflected in the copyright status of translations, which usually vest only in the author or publisher. The invisibility of the translator is problematic because, as post-colonial theorists of translation point out, the act of translation is 'not an innocent, transparent activity but is highly charged with significance at every stage; it rarely, if ever, involves a relationship of equality between texts, authors or systems' (Bassnett and Trivedi 1999:2).

The primacy of the 'original' text is partly related to the notion of Europe as the centre, when, as was the case historically, texts were translated for the use of the marginalised other and were seen as secondary (Bassnett and Trivedi 1999:4) and even as inferior (Grössel 1993:241), with the centre deciding what is translated, by whom, for whom, and for what purpose. Translation then becomes an overt or covert instrument of empire (Robinson 1997:60). Gonzales and Tolron (2006:vii) 
ask: 'To what extent can translation and the adaptation that it implies furnish access to a foreign culture? Is it possible or even desirable to attempt to transcend cultural barriers through translation... . ?' In this article, I contend that when it comes to texts which supply essential information, such as texts on indigenous law, we do not have the luxury of not making such an attempt.

In the case of Boonzaaier's 1990 text as a source text, it has a certain status as an academic text, and is being translated from the 'centre' in that sense. The text poses a special challenge, because it is an Afrikaans text about Nkuna culture. As an ethnographic text, it seeks to convey information about a culture that is not identical to the culture of the language in which the material is written (most translation theory assumes that a text is in transit between only two cultures at a time, those of the source and target text). The geographic and historical positioning of the text puts it in a Third World country with First World elements. In my case, I (like many other South African translators) am translating a text from the formerly hegemonic language of the region (Afrikaans) into the currently hegemonic language (English). Considering that the content focuses on what is generally regarded as the Third World, this translation is in itself a suspect activity in terms of post-colonial theory and my potential hermeneutic engagement with the content of the text in 2015, a full 25 years after the original text was written (pre-1994, in the last years before the end of apartheid). In a case where the translator is a person from a culture other than the culture described in the text (for example, a white woman like myself, as I am clearly not Nkuna), this problem is compounded.

Gonzales and Tolron (2006:vii) argue that the 'struggle to retain local specificity in the face of the pressures of globalisation puts translators in the role of cultural mediators . . . for marginal experiences'. This places a particular responsibility on the translator, especially when it comes to cases involving law (Cooke 1995:37-63). In this regard, then, a caveat expressed in the case of Alexkor Ltd and Another $v$ Richtersveld Community and Others (CCT19/03) [2003] ZACC 18 should be noted - the Constitutional court pointed out that "caution must be exercised when dealing with textbooks and old authorities because of the tendency to view indigenous law through the prism of legal conceptions that are foreign to it'. This warning, which focuses on the relation of author and reader, is equally important in respect of the prisms or filters the translator as reader and subsequent re-author may impose in assisting the text in transit between one language and another.

\section{Texts in Transit - Exploring the 'Edgeland'}

The source text as artefact is itself always a 'text in transit' (Blanchot 1971, cited in Venuti 1995:307), a text that is derivative in some form dependent on other preexisting materials. This is especially true of a research text such as an ethnographic study on Nkuna law, which relies on legal texts and other scholarly ethnographic 
texts for its method and perspective, the common Anglo-Saxon model for a research text (Stolze 2009:35), and oral tradition for much of its data. It is also a text exposed to cumulative future readings after its production, one of which is the translator's reading.

A text such as Boonzaaier's study as an ethnographic narrative, which occupies what Muncey (2010:29) refers to as an 'edgeland', crosses several boundaries and has to permeate through several filters, both in its creation, and its translation. The first filter relates to the ethnographic method itself (other filters include language, cultural, professional and gender discourses). This particular text, for example, was written by a white ethnographer trained at a South African university in the late 1970s and 1980s, and using a background of Roman Dutch and South African Common Law as his basis for comparison. He understands Xitsonga, but, in line with the expectations of tribal courtesy, in interviewing people in his fieldwork in the tribal area, he worked with an experienced senior member of the tribal court appointed by the hosi (the traditional leader). This court member acted as his guide and interpreter (enabling the researcher to verify finer nuances in the language and law) and also provided many of the sample cases used to illustrate the principles. Interviews were mainly in Xitsonga, so rewriting the field notes to construct the original research text in Afrikaans constitutes a translation that precedes the source text. This 'pretranslation' already posed a number of problems, such as the translation of terms for which there are no direct western [or South African] equivalents.

To give one example, consider the Xitsonga term $k u$ tshova rihlampfu. The term refers to the impregnation of an unmarried woman. Literally, the term means 'breaking the fence'. It implies that the man did not have the woman's father's permission to engage with the woman. Figuratively, the man did not come in by the kraal gate (the right way), but broke the fence (coming in the wrong way). The term also refers to the remedy - a fee paid to her father if the man intends to marry her. Jakobson's ([1959] 2004:140) argument that '[a]ll cognitive experience and its classification is conveyable in any existing language' still appears to be valid here - he did not suggest that there is an exact equivalent 'code-unit', but that there is always some analogue which allows communication. Translation is thus possible, but accurate translation may require extensive paraphrase.

Anthropologist Clifford Geertz (1988) warns that authorship inevitably involves imparting an identity and a personal signature to texts - thus anthropological writings are fictions, though not thereby necessarily 'unfactual', and often reflect particular power asymmetries related to the socio-historical conditions under which the texts are produced. Geertz (1988:3) points out that anthropological texts are highly constructed, using specific persuasive techniques to create a conviction of verisimilitude or Wahrscheinlichkeit, of the ethnographer's having 'been there'. Geertz (1988:7-8) explains that since the $18^{\text {th }}$ century, scientific discourses have tended to focus on content, while literary discourses have tended to focus on the 
authorial function. This led to an epistemological and methodological crisis (Peacock 1986; Grimshaw 2001) about issues of subjectivity in anthropological writing. This crisis was compounded by questions of the Eurocentricity of much ethnographic work opposed by decolonial theorists, such as Ndlovu (2014:43), who defines a decolonial perspective as

a cluster and combination of liberation projects involving critical thought about the excolonized epistemic sites. It seeks to make sense of the position of ex-colonized people within the current world-system, which Mignolo (2000) describes as a Euro-Americancentric, Christian-centric, patriarchal, capitalist, hetero-normative and racially-hierarchized, modern world-system.

The epistemological and methodological crisis pushed narratological and stylistic questions underground, leaving unaddressed what Geertz (1988:10) calls 'the oddity of constructing texts ostensibly scientific out of experiences [that are] broadly biographical'. Reading ethnography like literature is also an approach already suggested by Dell Hymes (1973:187-212), Gillian Beer (1983) and Marilyn Strathern (1987:251-281). It is beyond the scope of this article, and indeed the brief of the average translator, to consider the accuracy or 'reality' of anthropological texts. A translator has to trust the scientific narrative, and cannot usually verify its truth value. However, as a translator, in dealing with a scientific text, as a scientific narrative, one has to consider the construction, and the constructedness, of the text.

In the past, translation theory has focused largely on the text and sometimes on the translator as author. In line with the recent hermeneutic turn (Spivak [1992] 2012:315; Cercel 2009a, 2009b; Münch and Steinbach 2009; Stolze 2009), I contend that we need to look increasingly closely at the translator as a reader, who engages with the 'infinitely changing' and 'mutable' artefact of the text, because, as Wolfgang Iser (1974:xi) argues, it is the point of 'reader involvement [that] coincides with meaning production'. Iser (1974:279) describes the act of reading as 'a sort of kaleidoscope of perspectives, preintentions, recollections', an act in which ' $[t]$ he manner in which the reader experiences the text will reflect his own disposition . . . [an] apparently paradoxical situation in which the reader is forced to reveal aspects of himself in order to experience a reality which is different from his own' (Iser 1974:281-282). In this, Iser draws on Gadamer ([1960] 2004:300), who highlights the importance of a particular wirkungsgeschichtliches Bewußtsein (historically effected consciousness), because we are all embedded in the particular history and culture that shapes us. Thus when we interpret a text, that act requires a Horizontverschmelzung (fusion of horizons) where the reader finds the ways in which the text's history articulates with the reader's own background. The term Wirkungsgeschichte in itself implies a trajectory from the pre-reading stage, to what happens at the moment of reading, and to what happens afterwards. By foregrounding this dialectical structure, a translator can become more aware of the implications of particular diction and phrasing in the text. Iser (1974:xii) examines the 'prestructuring of the potential meaning by the 
text' and the 'reader's actualisation of this potential through the reading process'. Of particular interest to Iser is the 'negation' of the unfamiliar, which the reader tries to fill with the familiar, but with a resulting questioning of the familiar. $\mathrm{He}$ is also interested in the strategies which authors use to prestructure one response rather than another. Iser describes 'literary hermeneutics' as the space between text and theory, a 'no-man's-land', the 'topography' of which needs to be 'mapped' (Iser 1974:xii), mimicking the actions of early travel writers, and ethnographers. He claims that if a 'text does something to its readers, it also simultaneously reveals something about them' (Iser, 1989:vii), proposing a literary anthropology (Iser 1993) to examine this engagement.

The fusion of horizons between the author of the text and the translator (for example, in this post-apartheid reading in 2015 of the text written in 1990) in turn leads to the embedding of traces of my own historicity as a translator and as 'author' of the translated text in 2015. In translation, in addition to mediation between different times and places, there is also the issue of different cultures (however one defines that fraught term). Wagner (1975:2) claims, perhaps unjustly optimistically, that '[r]elative objectivity can be achieved through discovering what [our culture's basic assumptions] are, the ways in which one's culture allows one to comprehend another, and the limitations it places on this comprehension'. He admits: "Absolute" objectivity would require that the anthropologist [read: translator here] have no biases, and hence no culture at all' (Wagner 1975:2). Even with the best of intentions, a translator may recolonise, rather than decolonise (Robinson 1997:112) the text and thus the reader.

\section{Going from Reading to Writing - Crossing Boundaries}

At some point, the translator must stop being a reader and become a writer (RenaudGrosbras 2006:152). How does the translator address the need, as an author at a remove from the original ethnographic research, to present the details of the text as factually as possible? Does the translator have the right or even an obligation to mediate the text by inserting different spaces in the text, or even closing spaces, to make the text less sexist, more politically correct, for example? Moreover, how does a translator address the needs of a sufficiently wide spectrum of readers, as in South Africa, where the information needs of the judiciary, academics, and the broader public may differ? And how does a translator deal with the disparity of literacy levels on a continuum (Aitcheson 2001:134) in a given language in South Africa?

In the case study, the decision was made to translate the text into English for two pragmatic reasons. The first is the need among members of the judiciary and academics, especially since the democratic elections in 1994, for the academic text in a lingua franca (Noomé 2015:63-4), which, in the case of South Africa, is currently 
English, as it cannot be taken for granted that the Afrikaans text is accessible to all, including members of the Nkuna group themselves (for the Nkuna, who are first language Xitsonga speakers, English is the preferred second language) (Noomé 2015:11, 156-157). It seems that for the foreseeable future, English will continue to serve as South Africa's lingua franca (De Klerk 1996:8; Mail \& Guardian Sunday 14 June 2013:22-28; Noomé 2015:154; Titlestad 1996:165; Wright 1996:150-151, 2015:187), just as it is the official language and language that many parents choose for the education of their children in Namibia (Smit 2012). The second is the absence of qualified translators who are prepared to work from Afrikaans into Xitsonga (a translation into Xitsonga for members of the Nkuna would have been preferable, in many respects) - in March 2015, no accredited Afrikaans-Xitsonga translators were listed on the South African Translators' Institute (SATI) website, and only 18 English-Xitsonga translators, far too few to meet national demand.

Spivak, herself a noted translator, calls for complete engagement with the text. She writes that 'the translator must surrender to the text' (Spivak [1992] 2012:315; emphasis added). She adds: 'But no amount of tough talk can get around the fact that translation is the most intimate act of reading. Unless the translator has earned the right to become the intimate reader, she cannot surrender to the text, cannot respond to the special call of the text' (Spivak [1992] 2012:315; emphases added). So, in such an intimate engagement, what kinds of insight might a translator have? Let us look at some examples. (See Appendices A and B for the samples - the source text is given, with two possible translations. Note that these are not Plain English translations).

In Sample 1, the legal principle at stake is the kind of evidence that a man can bring before the court to prove that his wife has committed adultery. The author includes a court case where the husband brought to court the hat of a man whom the husband accused of adultery as evidence. The Afrikaans text uses legalistic language-getuienis, delikpleger, eiser, verweerder, owerspel and owerspelige man. Translation A renders these terms as evidence, testimony, the person accused of the delict, the claimant, defendant/accused, and refers to adultery and the adulterer. Translation B opts for a much more mixed style. It retains the terms relating to evidence, witnesses and adultery in the description of the principle, but chooses the term lover to describe the accused in the court case. This results in a very different case from the one in Translation A, making the story sound anecdotal and even entertaining, and minimises the delictual aspect of the incident. There is a risk that the somewhat light-hearted tone could make the translation sound patronising (this may be addressed by reconsidering the almost whimsical naming of the case by the author). Another interesting point is the translation of the misdemeanour itself - verkul, in the Afrikaans, becomes 'cheating on him' in both translations, but 'hy het hulle in owerspel betrap' is translated using the legalistic 'in flagrante delicto' in Translation A, and the euphemistic 'sleeping together' in Translation B. 
In the second sample, attitudes, beliefs and prevailing discourses may affect translation more obviously. In this sample, the legal principle involved relates to proving that a third party has impregnated the wife in the husband's absence, and the lengths to which a husband may go to extract evidence from the wife. The case title, 'The man who suspended his wife by her feet', tends to evoke instant reaction in readers, especially in the light of women's rights, the provision of freedom and security of the person in the Bill of Rights in the South African Constitution (Par 12), and the fact that corporal punishment is no longer permitted in schools in South Africa. The translator's attitude to marriage, faithfulness, pregnancy and spousal relations, as well as the extent to which the translator reads the case as implying spousal abuse will have a large effect on the translation. In the source text, the husband's action is worded as tugtig. Translation A translates this fairly directly as 'discipline' (implying the same unequal relationship suggested by the Afrikaans term). The adulterer is referred to as a verleier, rendered as a 'seducer' in Translation A (which places the blame on the third party). Translation B keeps the euphemistic 'discipline', but chooses 'lover' for the third party, opening up the issue of responsibility to include the woman. Translation A makes the woman sound like a naïve and sad victim of male power play and sanctioned marital violence, while Translation B arguably becomes a tacky tale of sexual adventure gone wrong.

It is evident that the variation possible has considerable implications for how subsequent readers will experience the text and the information it conveys. Thus careful engagement and negotiated decisions on the text are essential.

\section{CONCLUSION}

What then can a translator do? Venuti (1995:306) makes the following plea: 'A translated text should be the site where a different culture emerges, where a reader gets a glimpse of the cultural other.' This can be a very complicated task if the intended readership is as linguistically, culturally and educationally heterogeneous as the targeted readerships for the translations of this text are.

Nevertheless, the anomalous situation of translating a text within a country and the situatedness of the text and translators in South Africa opens up various possibilities. The multilingualism of Boonzaaier as the author (he speaks Afrikaans, English, Sepedi, and IsiZulu and understands Xitsonga) enabled me as a translator to consult with him as an author, as advocated by feminist translators, to verify and expand my hermeneutic engagement with the text. It allowed what Umberto Eco (2003:34) calls a 'negotiation' around a text in transit on laws in flux. The possibility of consulting with the author on the Skopos of the text - its purpose as defined by the person who commissions the translation (Vermeer [1989] 2012:191-193) - is particularly valuable in a legal anthropological text where the factual correctness of the text is vital. In this case, such consultation enabled closure of indeterminacies in 
this text, where indeterminacy is undesirable for the envisaged target readers. The translator's rereading of a legal anthropological text also allows a text to be revisited. In this case, considering the time that elapsed between the original research and the translation, it enabled essential updating of information, for example, on relevant national legislation and geographical place names.

Given the prevailing tradition of wanting a text that is 'beautiful' or at least easy to read, the end-users of a translation of this document will still expect and require a text in 'proper English', however one defines that. Even more, they need a text that is as accurate as possible, particularly if the text is to be used as a source for legal disputes. Translators play a pivotal role; they 'have a responsibility towards the author they are translating, but also toward the reader who presumably cannot read the text in its original version' (Poncharal 2006:129).

Some strategies that a translator can use to alert the reader to the translatedness of a text include what Venuti (1995:306) refers to as 'resistancy', a 'strategy based on an aesthetic of discontinuity' (Venuti 1995:306). This implies making visible throughout that a text $i s$ translated, by 'foreignizing' the text, for example, by using neologisms to suggest the original terms, or phrasing and structures that are idiomatic in the source language, but not in the target language. In our test case, the original author (Boonzaaier) explicitly described his research process, increasing his accountability for the process, and making his translation of Xitsonga terms in his field notes for inclusion in the Afrikaans research text less translucent. He also adopted the dual strategy of (1) translating a Nkuna technical term on first use and then reverting to the Nkuna word in italics where possible (for example, $n d z i h o$ [fine] in the two samples), and (2) providing a glossary of terms explaining nuances that a single Afrikaans term/phrase may fail to convey. Both strategies can be adopted in the English translations, but they cannot address all problems. Although my own brief was to focus on Nkuna (not Afrikaans) cultural elements, I added footnotes on translation choices for Afrikaans constructions that affect meaning.

A double translation is suggested for the case study text. The first is a metaphrastic one in an academic register, clarifying Nkuna tradition and using translators' notes, meticulously pointing out the imposition of a Common Law lens on indigenous law. The second is a far freer translation into Plain English, perhaps aimed specifically at a very broad Nkuna readership (whose literacy and English skills should not be absolutised), who already know much of their own law, inverting the lens, clarifying differences between Nkuna law and Common Law by focusing on the Nkuna perspective.

Another strategy, and one I would advocate, is increasing the visibility of the translator by adding at least a translator's preface to such texts, indicating key strategies followed in the translation, and defining 'the cultural and ideological underpinnings of [translators'] work' (Simon 1988:53), and for legal purposes, in the academic translation, translators' notes. Such notes would make the 'voice 
of the translator' heard, as advocated by feminist translators such as Homel and Simon (1988:44) and Flotow (1997:3). It would also add what Kwame Anthony Appiah ([1993] 2012:331-343), in a pointed allusion to Geertz's (1973:3-30) term 'thick description', refers to as 'thick translation' - a translation which explicates the context of details to readers from a different background, so that the margins can talk back to the centre. It is an issue that in the interests of accountability, authors and consumers (along with translators) should address. Indeed, the new South African Language Practitioners' Council Bill (South Africa, 2013), the implementation of which is currently still under discussion, may make disclosure of who translates what mandatory.

Meanwhile, the translator as the agent in this equation must bear in mind that, like the anthropologist or ethnographer, who writes in a certain time, and from a certain perspective, the translator as reader interprets and translates from a certain time and perspective. It should be made clear to readers, who need to be educated on the fact that translations are mutable constructions, that a text on indigenous law, especially in translation, reflects findings on the law at a specific point in time, and is merely a snapshot allowing them to trace how indigenous law continues to develop, as living law must.

In conclusion then, I would argue that perhaps it is a conscientious and accountable translator's task, in joining the ethnographer to become what Geertz (1988:147) refers to as an 'intercultural middleman' regarding the transmission of information on indigenous law, to foreground the dialogical moments of the translator's own reading activity, to engage and wrestle with that situatedness, and only then to embark on the act of writing, making explicit the additions and losses negotiated in the translation process.

\section{Note}

1. The translation (207 754 words, over 600 pages) is ongoing, in negotiation with C.C. Boonzaaier, the author.

\section{References}

Aitcheson, J. 2001. Reading and writing the new South Africa: Literacy and adult basic education and training in South Africa. In Knowledge, information and development: An African perspective, eds. C. Stilwell, A. Leach, A. and S. Burton, 134-152. School of Human and Social Studies Research Series No 1. Pietermaritzburg: University of Natal.

Alexkor Ltd and Another v Richtersveld Community and Others (CCT19/03) [2003] ZACC 18; 2004 (5) SA 460 (CC); 2003 (12) BCLR 1301 (CC) (14 October 2003). http://www.saflii. org/za/cases/ZACC/2003/18.pdf/ (accessed 6 July 2013). 
Appiah, K.A. [1993] 2012. Thick translation. In The translation studies reader, ed. L. Venuti, 331343. $3^{\text {rd }}$ edition. London: Routledge.

Bassnett, S. and Lefevere, A. General editors' preface. 1995. In L. Venuti, The translator's invisibility. A history of translation, vii-viii. London/New York, NY: Routledge.

Bassnett, S. and Trivedi, H. 1999. Post-colonial translation: Theory and practice. London/New York, NY: Routledge.

Beer, G. 1983. Darwin's plots: Evolutionary narrative in Darwin, George Eliot, and nineteenthcentury fiction. London, Boston, MA, Melbourne, and Henley: Routledge \& Kegan Paul.

Bhe and Others v Magistrate, Khayelitsha, and Others; Charlotte Shibi v Mantabeni Freddy Sithole and Others; SA Human Rights Commission and Others $v$ President of the Republic of South Africa and Others, 20051 SA 580 (CC)

Boonzaaier, C.C. 1990. Die familie-, erf-, en opvolgingsreg van die Nkuna van Ritavi met verwysing na ander aspekte van die privaatreg. Ongepubliseerde D Phil (Volkekunde) tesis, Universiteit van Pretoria, Pretoria.

Cercel, L. 2009a. Auf den Spuren einer verschütteten Evidenz: Übersetzung und Hermeneutik. In Übersetzung und Hermeneutik / Traduction et herméneutique, ed. L. Cercel, 7-15. Bucharest: Zeta Books.

Cercel, L. 2009b. Übersetzen als hermeneutischer Prozess. Fritz Paepke und die Grundlagen der Übersetzungswissenschaft. In Übersetzung und Hermeneutik / Traduction et herméneutique, ed. L. Cercel, 331-357. Bucharest: Zeta Books.

Cooke, M. 1995. Understood by all concerned? Anglo/Aboriginal legal translation. In Translation and the law, ed. M. Morris, 37-63. American Translators Association Scholarly Monographs Series. Vol. VIII. Amsterdam \& Philadelphia, PA: Benjamins.

De Klerk, V. 1996. Introduction. In Focus on South Africa, ed. V. de Klerk, 7-17. Varieties of English Around the World, General Series 15. Amsterdam \& Philadelphia, PA: John Benjamins.

Eco, U. [2003] 2004. Mouse or rat? Translation as negotiation. London: Phoenix.

Flotow, L. von. 1997. Translation and gender: Translating in the era of feminism. Manchester: St Jerome.

Gadamer, H.-G. [1960] 2004. Truth and Method. 2nd rev. edition. Trans. J. Weinsheimer and D. G. Marshall. New York, NY: Crossroads.

Geertz, C. 1973. The interpretation of cultures. New York: Basic Books.

Geertz, C. 1988. Works and lives. The anthropologist as author. Stanford, CA: Stanford University Press.

Gonzalez, M. and Tolron, F. eds. 2006. Introduction: Towards a contemporary poetics of translation. In Translating identity and the identity of translation, eds. M. Gonzalez and F. Tolron, vi-x. Newcastle: Cambridge Scholars Press.

Grimshaw, A. 2001. The ethnographer's eye. Ways of seeing in modern anthropology. Cambridge: Cambridge University Press.

Grössel, H. 1993. Übersetzungskritik - Wo und von wem? In Vom schwierigen Doppelleben des Übersetzers, Hrsg. K. Graf, 240-251. Berlin: Volk \& Welt. 
Homel, D. and Simon, S. eds. 1988. Mapping literature. The art and politics of translation. Montréal: Véhicule Press.

Hymes, D. 1973. An ethnographic perspective. New Literary History. A Journal of Theory and Interpretation, 5(1), Autumn: 187-212.

Iser, W. 1974. The Implied reader. Patterns of communication in prose fiction from Bunyan to Beckett. Baltimore, MD: Johns Hopkins University Press. (translated from 1972. Der implizite Leser: Kommunikationsformen des Romans von Bunyan bis Beckett, translator unnamed).

Iser, W. 1989. Prospecting. From reader response to literary anthropology. Baltimore, MD: Johns Hopkins University Press.

Iser, W. 1993. The fictive and the imaginary. Charting literary anthropology. Baltimore, MD: Johns Hopkins University Press. Tr. David Henry Wilson.

Jakobson, R. [1959] 2004. On linguistic aspects of translation. In The translation studies reader, ed. L. Venuti, 138-144. $2^{\text {nd }}$ edition. London: Routledge.

Kelto, A. 2012. South Africa Considers Legislation to Give Tribal Courts Authority. The World, 21 June. http://www.theworld.org/2012/06/south-africa-tribal-courts/. Accessed: 5 July 2013.

Kleyn, D. and Viljoen, F. 2010. Beginner's Guide for Law Students. $4^{\text {th }}$ edition. Cape Town: Juta. Mail \& Guardian, Sunday 14 June 2013, 22-28.

Modjadji Florah Mayelane v Mphephu Maria Ngwenyama and Another. CCT 57/12. [2013] ZACC 14. Date of hearing: 20 November 2012. Date of delivery: 30 May 2013. Media Summary. www.saflii.org/za/cases/ZACC/2013/ 14media.pdf. Accessed: 5 July 2013.

Modjadji Florah Mayelane v Mphephu Maria Ngwenyama and Another. CCT 57/12. [2013] ZACC 14. Date of hearing: 20 November 2012. Date of delivery: 30 May 2013. http://www. saflii.org/za/cases/ZACC/2013/14.pdf./ (accessed 5 July 2013).

Muncey, T. 2010. Creating autoethnographies. London: Sage.

Münch, H.O. and Steinbach, I. 2009. Verstehen und Geltung: Gadamers Hermeneutik im kritischen Licht der Übersetzungswissenschaft. In Übersetzung und Hermeneutik / Traduction et herméneutique, ed. L. Cercel, 167-186. Bucharest: Zeta Books.

Ndlovu, M. 2014. Cultural villages in post-apartheid South Africa: A decolonial perspective. PhD thesis, Monash University, Australia.

Noomé, I. 2015. Widening readership - A case study of the translation of indigenous law. Unpublished DLitt thesis, University of Pretoria, Pretoria, South Africa.

Peacock, J.L. 1986. The anthropological lens. Harsh light, soft focus. Cambridge: Cambridge University Press.

Poncharal, B. 2006. The translation of social science texts: Preserving coherence. In Translating identity and the identity of translation, eds. M. Gonzalez and F. Tolron, 119-131. Newcastle: Cambridge Scholars Press.

Renaud-Grosbras, P. 2006. The translator's unconscious. In Translating identity and the identity of translation, eds. M. Gonzalez and F. Tolron, 152-161. Newcastle: Cambridge Scholars Press.

Robinson, D. 1997. Translation and Empire: Postcolonial theories explained. Manchester: St. Jerome. 
Simon, S. 1988. Out from undercover. In Mapping literature. The art and politics of translation, eds. D. Homel and S. Simon, 51-54. Montréal: Véhicule Press.

Smit, T.C. 2012. Is 'English-centric bilingualism' suffocating Namibian national and indigenous languages? Nawa: Journal of Language and Communication, 6(2), December:82-94.

South Africa. 1988. Law of Evidence Amendment Act, 47 of 1988. Pretoria: Government Printer.

South Africa. 1996. Constitution of the Republic of South Africa, Act 108 of 1996. http://www.gov. za/sites/www.gov.za/files/Act108of1996s.pdf. (accessed 29 July 2015).

South Africa. 2013. South African Language Practitioners' Council Bill. [Online] Available at: https://jutalaw.co.za/media/filestore/2013/06/b_14_-_2013_-_South_African_Language_ Practitioners_Council_Bill.pdf/(accessed: 27 March 2015.

Spivak, G.C. [1992] 2012. The politics of translation. In The translation studies reader, ed. L. Venuti, 312-330. $3^{\text {rd }}$ edition. London: Routledge.

Stolze, R. 2009. Hermeneutik und Übersetzungswissenschaft: Eine praxisrelevante Verknüpfung. In Übersetzung und Hermeneutik / Traduction et herméneutique, ed. L. Cercel, 19-49. Bucharest: Zeta Books.

Strathern, M. 1987. Out of context. The persuasive fictions of anthropology. Current Anthropology, 28(3), June: 251-281.

Titlestad, P. 1996. English, the Constitution and South Africa's language future. In Focus on South Africa, ed. V. de Klerk, 163-174. Varieties of English Around the World, General Series 15. Amsterdam \& Philadelphia, PA: John Benjamins.

Venuti, L. 1995. The translator's invisibility. A history of translation. London/New York, NY: Routledge.

Vermeer, H. [1989] 2012. Skopos and commission in translational action. Transl. by A. Chesterman. In The translation studies reader, ed. L. Venuti, 191-202. $3^{\text {rd }}$ edition. London: Routledge.

Wagner, R. 1975. The invention of culture. Englewood Cliffs, NJ: Prentice-Hall.

Wright, L. 1996. The standardisation question in Black South African English. In Focus on South Africa, ed. V. de Klerk, 149-162. Varieties of English Around the World, General Series 15. Amsterdam \& Philadelphia, PA: John Benjamins.

Wright, L. 2015. Why English dominates the central economy: An economic perspective on 'elite closure' and South African language policy. In Language policy and political economy: English in a global context, ed. T. Ricento, 187-208. New York, NY: Oxford University Press.

Yevtushenko, Y. n.d. 'Translation is like a woman.' BrainyQuote.com. www.brainyquote.com/ quotes/quotes/y/yevgenyyev391310.html./(accessed 6 July 2013). 


\begin{tabular}{|c|c|c|}
\hline Appendix A: Case 45 & Translation A: & Translation B: \\
\hline $\begin{array}{l}\text { Die blote getuienis van die man dat sy vrou met 'n } \\
\text { ander man owerspel gepleeg het, word nie as } \\
\text { voldoende beskou nie maar moet met addisionele } \\
\text { getuienis gestaaf word. Waar getuies nie geroep kan } \\
\text { word nie, moet die man iets persoonlik soos ' } n \\
\text { kledingstuk of ' } n \text { kierie waaraan hy geïdentifiseer } \\
\text { kan word, van die delikpleger sal afneem wanneer } \\
\text { hy hom in owerspel betrap. Dit word dan die taak } \\
\text { van die verweerder om aan die hof 'n bevredigende } \\
\text { verduideliking te verstrek oor hoe die betrokke } \\
\text { artikel in die eiser se besit kon gekom het. Indien die } \\
\text { verweerder nie 'n bevredigende verduideliking in die } \\
\text { verband kan gee nie, word die verweerder vir die } \\
\text { owerspel aanspreeklik gehou. Die volgende saak } \\
\text { illustreer hierdie beginsel. }\end{array}$ & $\begin{array}{l}\text { It is not enough for a man to testify that his wife } \\
\text { has committed adultery with another man. } \\
\text { Additional evidence must be brought before the } \\
\text { court. Where witnesses cannot be called, the } \\
\text { husband must take a personal possession, such as } \\
\text { an article of clothing or a walking stick (kierie) } \\
\text { from the person accused of the delict which can be } \\
\text { identified as belonging to the adulterer when the } \\
\text { husband catches the adulterer. The onus is then on } \\
\text { the accused to provide the court with a satisfactory } \\
\text { explanation of how the article concerned fell into } \\
\text { the claimant's hands. If the defendant cannot give } \\
\text { a satisfactory explanation in this regard, the } \\
\text { defendant will be held liable for adultery. The } \\
\text { following case illustrates this principle. }\end{array}$ & $\begin{array}{l}\text { It is not enough for a man to testify that his wife } \\
\text { has committed adultery with another man. } \\
\text { Additional evidence must be brought before the } \\
\text { court. Where the husband cannot provide } \\
\text { witnesses, the husband must take a personal } \\
\text { possession, such as some clothing or a walking } \\
\text { stick (kierie) from the adulterer which can be } \\
\text { identified as belonging to the adulterer. The } \\
\text { adulterer must then provide the court with a } \\
\text { satisfactory explanation of how the husband got } \\
\text { hold of the article concerned. If the adulterer } \\
\text { cannot give a satisfactory explanation in this } \\
\text { regard, he is held liable for adultery. The following } \\
\text { case illustrates this principle. }\end{array}$ \\
\hline $\begin{array}{l}\text { Saak 45: Die owerspelige man wat sy hoed } \\
\text { vergeet het } \\
\text { 'n Man A het 'n vermoede gehad dat sy vrou hom } \\
\text { verkul. Toe sy vrou dus op 'n dag weer sy kraal } \\
\text { verlaat onder die voorwendsel dat sy hout gaan } \\
\text { optel, het A haar op 'n veilige afstand gevolg. A se } \\
\text { vrou het toe 'n bos ingegaan waar sy 'n ander man, } \\
\text { B, ontmoet het. Toe A die bos bereik, was hy betyds }\end{array}$ & $\begin{array}{l}\text { Case 45: The adulterer who forgot his hat } \\
\text { A man A suspected his wife of cheating on him. } \\
\text { One day, when the wife left the kraal again, on the } \\
\text { pretext of going to gather some wood, A followed } \\
\text { her at a safe distance. A's wife went into a thicket } \\
\text { where she met another man, B. A reached the } \\
\text { forest in time to catch his wife and B in flagrante } \\
\text { delicto. A's wife and the adulterer (B) managed to }\end{array}$ & $\begin{array}{l}\text { Case 45: The lover who forgot his hat } \\
\text { A husband suspected his wife of cheating on him. } \\
\text { One day, when the wife left the kraal, saying that } \\
\text { she was going to gather some wood, the husband } \\
\text { followed her at a safe distance. The wife went into } \\
\text { the forest where she met another man. The } \\
\text { husband reached the forest in time to catch his } \\
\text { wife and the other man sleeping together. The wife } \\
\text { and her lover managed to scramble to their feet }\end{array}$ \\
\hline
\end{tabular}


om sy vrou en B in owerspel te betrap. A se vrou en die delikpleger (B) het daarin geslaag om op te spring en weg te hardloop. In sy haas om weg te kom het B egter sy hoed vergeet. A het B se hoed toe na sy kraal geneem waar hy dit in die lug gehou en die mense gevra het of hulle die hoed herken. Alma het die hoed as dié van B geëien.

A het die saak toe na die familiehof geneem waar almal B se hoed herken het. B kon nie 'n

bevredigende verduideliking aan die hof gee oor die wyse waarop sy hoed in A se besit gekom het nie. Gevolglik het hy erken dat hy owerspel met A se vrou gepleeg het. B is toe beveel om die vasgestelde hoeveelheid ndziho van daardie tyd vir owerspel, te wete twee beeste en een bok, aan A te lewer. Na die hofsaak is B se hoed, volgens die reël, aan hom teruggegee. jump up and run away. In his haste to get away, B forgot his hat. A took B's hat back to his kraal, where he held the hat up and asked the people in the kraal whether they recognized the hat.

Everyone present recognized the hat as belonging to $\mathrm{B}$.

The husband took the case to the family court, where everyone recognised the hat as belonging to B. B was unable to give a satisfactory explanation of how the hat had come into A's possession.

As a result, $\mathrm{B}$ admitted that he had committed adultery with A's wife. The adulterer was then ordered to pay the stipulated $n d z i h o$ [fine] for adultery, to wit, two head of cattle and one goat, to the husband. After the court case, the hat, in accordance with the rules, was returned to the adulterer. and ran away. However, in his haste, the lover left behind his hat. The husband picked up the hat and took it back to his kraal. He held the hat up and asked the people in the kraal whether they recognized it. Everyone present recognized the hat as belonging to the lover.

The husband took the case to the family court. Everyone in the court recognized the hat and identified its owner. The lover was unable to explain how the husband had obtained the hat.

The lover had to admit that he had committed vooswi [adultery] with the wife. The lover was ordered to pay the stipulated ndziho for vooswi, at that time it was one goat plus cattle (two animals), to the husband. After the court case, the hat, in accordance with the rules, was returned to the lover

\section{Appendix B: Case 47}

\section{Saak 47: Die man wat sy vrou aan haar voete} opgehang het

$\mathrm{Na}$ ' $\mathrm{n}$ onafgebroke tydperk van 1 jaar in

Johannesburg, het ' $\mathrm{n}$ man A bevind dat sy vrou (B) swanger was. Hy kon nie vir die swangerskap verantwoordelik wees nie, dus het A vir B gevra wie haar beswanger het. B het ontken dat sy swanger is. Die mediese dokter by die Shiluvanesendinghospitaal het die swangerskap bevestig. A het $B$ toe na die hoofkraal geneem waar sy vir twee weke lank elke nag in 'n sel toegesluit is om haar te laat erken dat sy swanger is en wie haar verlei het. Dit was egter tevergeefs. A het die

\section{Translation A:}

Case 47: The husband who suspended his wife by her feet

When Man A returned home after a year spent working in Johannesburg, he found his wife (B) pregnant. Because he could not be responsible for the pregnancy himself, A asked B who had got her pregnant. B denied that she was pregnant. A took her to a doctor at the Shiluvhane mission hospital, and the doctor confirmed her pregnancy. A then took B to the main kraal where she was locked up in a cell every night for two weeks to make her admit that she was pregnant and to say who had seduced her. This did not work. A then asked the

\section{Translation B}

\section{Case 47: The husband who suspended his wife}

\section{by her feet}

A husband returned home from Johannesburg, where he had been working, after a year. He found his wife pregnant. He knew he could not be responsible for the pregnancy himself, so he asked his wife who had got her pregnant. The wife denied that she was pregnant. The husband then took the wife to a doctor at the Shiluvhane mission hospital. The doctor confirmed her pregnancy. The husband then took the wife to the main kraal where she was locked up in a cell every night for two weeks to force her to confess that she was 


\begin{tabular}{|c|c|c|}
\hline $\begin{array}{l}\text { stamhoof versoek om B los te laat en aangevoer } \\
\text { dat hy weet hoe om die inligting uit haar te kry. } \\
\text { Die versoek is toegestaan en A het B na sy kraal } \\
\text { teruggeneem. As gevolg van B se swangerskap } \\
\text { kon A haar nie lyfstraf toedien nie. B was egter } \\
\text { geneig tot drankmisbruik. A het sy vrou se } \\
\text { swakheid uitgebuit en aan B 'n bottel brandewyn } \\
\text { gegee wat sy uitgedrink het. Toe B goed dronk is, } \\
\text { het hy B aan haar voete aan die hut se dakbalk } \\
\text { opgehang. B het toe die naam van die persoon wat } \\
\text { haar beswanger het, bekendgemaak en gepleit dat } \\
\text { A haar moes losmaak. A het egter eers twee } \\
\text { getuies gaan roep en eers nadat B die naam van die } \\
\text { verleier aan die twee getuies herhaal het, vir B } \\
\text { losgemaak. In die stamhof het die verleier } \\
\text { aanvanklik die klag ontken. B se getuienis dat hy } \\
\text { vir haar swangerskap verantwoordelik was tesame } \\
\text { met die feit dat A kon bewys dat hy nie gedurende } \\
\text { die tyd wat B bevrug is, in die stamgebied was nie, } \\
\text { het die verleier egter laat erken dat hy met B } \\
\text { owerspel gepleeg het en dus vir haar swangerskap } \\
\text { verantwoordelik kon wees. B het aangevoer dat } \\
\text { die verweerder haar allerhande mooi goed belowe } \\
\text { het as sy sy naam sou verswyg. Die verweerder het } \\
\text { egter ontken dat hy so 'n omkoopbelofte aan B } \\
\text { gemaak het. Die verleier is beveel om R50 as } \\
\text { ndziho aan A te betaal. }\end{array}$ & $\begin{array}{l}\text { hosi to release B and claimed that he knew how to } \\
\text { get the information out of her. His request was } \\
\text { granted and A took B back to his kraal. Because of } \\
\text { B's pregnancy, A could not discipline her. } \\
\text { However, B tended to abuse alcohol. A exploited } \\
\text { his wife's weakness and gave B a bottle of brandy, } \\
\text { which she consumed to the dregs. When A saw } \\
\text { that B was very drunk, he suspended her by her } \\
\text { feet from the hut's roof pole. B then confessed the } \\
\text { name of her seducer. Before A untied B, A first } \\
\text { called two witnesses, and only untied B when she } \\
\text { had named the seducer in front of the two } \\
\text { witnesses. In the tribal court, the seducer initially } \\
\text { denied the charge. However, B's testimony that he } \\
\text { was responsible for the pregnancy and the fact that } \\
\text { A could prove that he was absent from the tribal } \\
\text { area when she became pregnant forced the seducer } \\
\text { to admit that he had committed adultery with B } \\
\text { and was therefore responsible for her pregnancy. B } \\
\text { said that he had promised her all kinds of nice } \\
\text { things if she would keep his name a secret. This } \\
\text { attempt at bribery was denied by the seducer. The } \\
\text { court orders the seducer to pay R50 ndziho to A. }\end{array}$ & $\begin{array}{l}\text { pregnant and to name her lover. In vain. The } \\
\text { husband then asked the hosi to release the woman, } \\
\text { because he said he knew just how to get the } \\
\text { information out of her. His request was granted } \\
\text { and the husband took the wife back to his kraal. } \\
\text { Because the woman was pregnant, the husband } \\
\text { could not apply corporal punishment. However, } \\
\text { the wife tended to abuse alcohol. The husband } \\
\text { gave her a bottle of brandy, which she drank to the } \\
\text { last drop. When the husband saw that the wife was } \\
\text { drunk, he hung her by her feet from the hut's roof } \\
\text { pole. The wife then named the lover. Before the } \\
\text { husband untied her, he first called two witnesses, } \\
\text { and only untied her when she had named her lover } \\
\text { in front of the two witnesses. In the tribal court, } \\
\text { the lover at first claimed he was innocent. But the } \\
\text { wife's testimony that he was responsible for the } \\
\text { pregnancy and the fact that the husband could } \\
\text { prove that the husband was absent from the tribal } \\
\text { area when she became pregnant forced the lover to } \\
\text { admit that he had slept with the wife and was } \\
\text { therefore responsible for her pregnancy. The wife } \\
\text { then said that her lover had promised her all kinds } \\
\text { of nice things if she would keep his name a secret. } \\
\text { The lover denied this, but was ordered by the court } \\
\text { to pay R50 ndziho to the husband. }\end{array}$ \\
\hline
\end{tabular}

